Review article

UDC:611.92/93:616-002-073.7

doi: $10.5633 / \mathrm{amm} .2017 .0211$

\title{
IMPORTANCE OF COMPUTED TOMOGRAPHY IN THE DIAGNOSIS OF HEAD AND NECK INFECTIONS
}

\author{
Slađana Petrović1,2, Aleksandra Milenković3 ${ }^{3}$ Milan Stojanović3, \\ Maja Jocić ${ }^{\text {, Filip Petrović }}{ }^{2}$, Dragan Stojanov ${ }^{1,2}$
}

Clinical Center Niš, Institute of Radiology, Niš, Serbia1

University of Niš, Faculty of Medicine, Niš, Serbia2

University of Priština, Faculty of Medicine, temporarily seated in Kosovska Mitrovica3

Contact: Slađana Petrović

Faculty of Medicine, University of Niš,

Boulevard Dr Zorana Đinđića 81, 18000 Niš

e-mail: sladjana-petrovic@hotmail.com

Head and neck infections are a group of disorders that can be accompanied by serious complications with an extent that is hard to estimate. Although their occurrence has significantly decreased due to the use of antibiotic and improvements in oral hygiene in modern times, there still exists a high rate of morbidity and mortality of these infections. A complex anatomy and communications between spaces in this region favor the spread of these processes and can lead to life-treating conditions such as airway obstruction, empyema, mediastinitis, thrombophlebitis, pericarditis and septic shock.

Computerized tomography (CT), as a method of choice in emergency conditions of the head and neck region, allows a fast and accurate diagnosis, estimation of the disease spread and potential complications. Acta Medica Medianae 2017;56(2):70-77.

Key words: head and neck infections, complications, CT 